УДК 35.072.2(477)

DOI: $10.34132 /$ pard2021.11.12

\title{
ЗАГАЛЬНІ ЗАСАДИ ЗАБЕЗПЕЧЕННЯ ВІДКРИТОСТІ ТА ПРОЗОРОСТІ ОРГАНІВ ПУБЛІЧНОЇ ВЛАДИ В УКРАЇНІ
}

Tимофсєв C. П., канд. наук 3 держ. упр., доцент, Інститут державного управління, Чорноморський національний університет імені Петра Могили, м. Миколаїв, Україна.

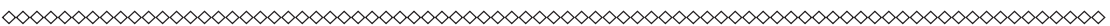

Статтюприсвяченодослідженнюєзагальнихзасадзабезпечення відкритості та прозорості органів публічної влади та встановленню особливостей реалізацію цุих принщипів в Україні на сучасному етапі. Відмічається, щуо до переваг децентралізованої моделі публічного управління можна віднести реальну форму здійснення місцевого народовладдяувідповідностідемократичним принципам управління, врахування в першу чергу саме інтересів і потреб місиевої громади, ефективне та швидке рішення місиевих проблем, розпорядження власними ресурсами, фінансова самостійність. Визначено, щзо основними ознаками розвинутого місиевого самоврядування $\epsilon$ забезпечення прозорості та відкритості; иироке використання прямої демократії; доступність для звернень громадян та зворотного зв>язку; мінімізованій рівень або відсутній корупиії. Встановлено, щзо основні напрямки реалізації принципів прозорості та відкритості діяльності органів публічної влади: об'єктивний та всебічних розгляд звернень; консультування з представниками громадянського суспільства; проведення комунікативних заходів; систематична діяльність з паблік рилейшнз.

Ключові слова: органи публічноївлади, відкритість, прозорість, громадськість, підзвітність, комунікації.

Постановка проблеми у загальному вигляді. В сьогоднішніх умовах розбудови демократичного врядування в Україні результативність та ефективність діяльності влади певною мірою 
залежать від налагодженої взаємодії з громадськістю. В свою чергу ступінь довіри громадян до органів публічної влади відображає відношення громадян до їх діяльності, котре залежить від низки факторів. Беззаперечно, на першому плані серед факторів впливу постають рівень життя населення та загалом соціально-економічна стабільність. Разом 3 тим, вагоме місце займають відкритість та прозорість влади, в яких громадяни вбачають підзвітність, готовність працювати на благо народу, справжню чесність представників влади тощо. Саме тому разом з забезпеченням суспільного добробуту органам публічної влади слід звертати увагу на забезпечення загально визнаних демократичних принципів, що в свою чергу налаштовує громадянськість та інститути громадянського суспільства на плідну співпрацю та участь у спільному вирішенні владно-управлінських проблем. Таким чином, питання прозорості та відкритості має вагоме значення та заслуговує на дослідження, особливо в умовах децентралізації влади в Україні, коли проходить суцільне реформування адміністративно-територіального устрою та передача переважної більшості владних повноважень на місцевий рівень.

Аналіз останніх досліджень і публікацій. Питання прозорості та відкритості органів публічної влади, забезпечення доступу до публічної інформації та різні аспекти їх реалізації в Україні знайшли своє відображення у значної кількості дослідників, серед яких можна назвати наступних: О. Батанов, А. Буханевич, С. Влащенко, М. Воронов, М. Гравцов, О. Грибко, Е. Дмитренко, В. Дронов, О. Євтушенко, Ю. Ковтун, І. Куспляк, І. Лопушинський, Б. Мицак, I. Мінаєва, В. Нестерович, Ю. Ніронка, І. Парубчак, Ф. Семенченко, I. Ткач, Н. Шотурма тощо. Однак, разом із цим на сьогодні зазначене питання не втрачає актуальності та вимагає ретельного аналізу в умовах проведення реформування адміністративно-територіального устрою.

Формулювання цілей статті (постановка завдання). Метою дослідження є визначення загальних засад забезпечення відкритості та прозорості органів публічної влади та встановлення особливостей реалізацію цих принципів в Україні на сучасному етапі. 
Виклад основного матеріалу дослідження. У системі публічної влади значна роль належить місцевому самоврядуванню, як сфері публічної діяльності, у якій може взяти участь кожний громадянин. Місцева влада, як вже нами було зазначено, є складовою публічної влади та є важливим у взаємозв'язку між державою та громадянином. Адже питання місцевого значення значно ефективніше вирішувати саме на місцевому рівні з залученням громади до обговорення [11, с. 55]. Проте, деякі питання, все ж таки, вирішуються на рівні державному, із залученням централізованих засобів і ресурсів. Сюди можна віднести: забезпечення територіальної цілісності і незалежності держави; створення єдиної правової бази; розробку i впровадження зовнішньої державної політики; конституційне визнання та гарантії основних прав і свобод громадян; прийняття і реалізацію державних програм (у галузі науки, культури, освіти, охорони здоров'я, соціального захисту, правопорядку і безпеки) та ін. Ці питання зазначені у Основному Законі держави та закладають основу публічної влади в цілому.

У той же час, як було зазначено вище, реалізація багатьох функцій буде ефективніше саме на місцях. Це, наприклад, питання безпеки, надання медичної допомоги, освітні питання, створення робочих місць, питання транспортних сполучень, надання якісних побутових та комунальних послуг. Все це має бути віднесено до компетенції саме органів місцевого самоврядування для вирішення на території певної адміністративно-територіальної одиниці.

Також важливо зазначити, що 3 розвитком демократичного суспільства все більше держав передають повноваження 3 центру на місця шляхом децентралізації. Даний процес робить можливим збільшити ефективність надання послуг у відповідність із потребами i запитами певної громади. Так, за висловом американського науковця О. Тоффлера, перехід до децентралізації - це «глобальний зсув влади», що звільняє особу від державної опіки і дозволяє будувати демократію знизу догори [7, с. 51].

Варто звернути увагу, що важливість інституту місцевого самоврядування базується на можливості громади приймати участь у вирішенні питань місцевого значення, реалізовуючи свої інтереси 
у цій сфері, до яких можуть не прислухатись на загальнодержавному рівні [24, с. 98].

Говорячи про місцеве самоврядування в Україні на сьогодні, слід приділяти увагу триваючому процесу реформи децентралізації. Реформа децентралізація, яка була розпочата в Україні у 2014 році, та супроводжується процесом об'єднання територіальних громад, на сьогодні є однією з найбільш обговорюваних тем та напрямів реформ в Україні успішна реалізація якої має стати підгрунтям для створення дійсно спроможних територіальних громад. Кінцевою метою створення нової моделі місцевого самоврядування в Україні $\epsilon$, насамперед, забезпечення його спроможності самостійно, за рахунок власних ресурсів, вирішувати питання місцевого значення.

Характеризуються децентралізовану модель самоврядування на місцях в цілому, то варто зазначити, що насамперед вона передбачає надання повної самостійності органам місцевого самоврядування територіальних громад. Реалізація даної моделі стає причиною до розвитку територій, стрімких соціальних та економічних досягнень на місцях, що стає можливим через збалансованість соціальних та економічних місцевої та державної економіки.

До переваг даної моделі місцевого самоврядування можна віднести реальну форму здійснення місцевого народовладдя у відповідності демократичним принципам управління, врахування в першу чергу саме інтересів і потреб місцевої громади, ефективне та швидке рішення місцевих проблем, розпорядження власними ресурсами, фінансова самостійність.

Основою такої моделі $є$ не лише принцип децентралізації влади, а й європейський принцип субсидіарності, який полягає у делегуванні на державний рівень лише ті повноваження, які громада не може здійснювати самостійно через певні економічні або соціальні причини [10, с. 86].

Варто зазначити, що даний принцип $\epsilon$ загальним для інституціоналізації влади і управління. Відповідно до нього, на практиці держава втручається у справи місцевого управління лише у тому випадку, якщо без іiі допомоги досягти поставлених цілей неможливо. 
Децентралізована модель вказує не лише на повноваження органів місцевого самоврядування, а й веде за собою утвердження децентралізованої системи управління державою, в якій взаємовідносини між органами державної влади й органами місцевого самоврядування будуються на принципах реальної децентралізації.

Отже, саме децентралізована модель влади, яку на сьогодні було обрано як модель розбудови системи публічного управління в Україні, відповідає міжнародним та європейським стандартам та $\epsilon$ найбільш демократичною та вигіднішою для простого населення громад [16].

Ключовим питанням, яке необхідно розв'язати в ході реформування, є забезпечення передачі максимально можливого обсягу владних повноважень органам місцевого самоврядування та чіткого їх розмежування з повноваженнями виконавчої влади. На сьогодні стоїть важливе завдання визначення та запровадження в Україні власної моделі децентралізації в управлінні, яка дозволить досягти значно більшого рівня ефективності публічного управління для забезпечення громадян необхідною кількістю та якістю соціальних та адміністративних послуг. У зв’язку з цим необхідно визначити зміст та форму децентралізації як умови розвитку місцевого самоврядування, адже існуючий стан справ свідчить про незавершеність формування місцевого самоврядування в Україні.

Під час розгляду реформування місцевого самоврядування необхідно враховувати перелічені ризики та передбачати застосування механізмів послаблення їх негативного впливу. В свою чергу поява тих чи інших складностей стимулюватиме до швидкого реагування влади та пошуку засобів вирішення існуючих проблем. На сучасному етапі увагу потрібно зосередити на забезпеченні втілення принципу субсидіарності як засобу подолання конфлікту інтересів між місцевими органами виконавчої влади та органами місцевого самоврядування. Принцип субсидіарності має стати основою для забезпечення розподілу повноважень під час реформування територіальної організації влади, залучення громадян до прийняття управлінських рішень. Взагалі для зміцнення місцевого 
самоврядування важливо цей принцип закріпити у профільному законі «Про місцеве самоврядування в Україні», запровадження якого слугуватиме механізмом стримування централізації [11, с. 57].

Територіальна громада в Україні є основним суб'єктом місцевого самоврядування. Обираючи курс децентралізації для адміністративно-територіальної реформи, у державі розпочався процес об〉єднання територіальних громад, що триває вже п’ять років. Такими чином, сьогодні можна сказати, що якщо територіальна громада $\epsilon$ основною ланкою побудови системи місцевого самоврядування, то ОТГ - є основою децентралізації.

Варто зазначити, що формування в Україні ОТГ, яке розпочалось 3 прийняттям Закону України «Про добровільне об〉єднання територіальних громад» (2015), повинно не лише враховувати бажанням громади, а й відповідати державній політиці децентралізованого управління. Адже метою реформи є побудова спроможних та ефективних, економічно самостійних ОТГ, які впораються із наданими їм повноваженням, ресурсами і будуть змозі нести відповідальність [7, с. 119].

Слід відмітити, що реалізація на практиці децентралізації влади відбувається на двох рівнях: стратегічному та тактичному. Так, на першому рівні виробляється стратегія започаткування та подальшого розвитку публічного управління такої форми, оцінка потреб та закликів суспільства та розробка відповідного плану дій для досягнення мети. У випадку України - даним етапом стало прийняття Концепції.

Проте, варто зазначити, що таке прогнозування повинно керуватись реальними статистичними даними, які будуть стабільними тривалий час. Адже без стабільних значень фактично не можливо спланувати ефективну стратегію розвитку. В тому числі це стосується політичної стабільності та відсутності економічних криз.

На тактичному рівні відбувається подолання тих недоліків, які стали очевидними під час практичної реалізації стратегії реформування, вдосконалення окремих механізмів іiі реалізації, налагодження взаємодії між суб'єктами реформи, внесення відповідних змін до законодавства. 
Варто зазначити, що без компетентного розуміння проблемних питань, які виникають на тактичному рівні, неможливе належним чином розробити рівень стратегічний розроблення на рівні стратегічному [1, с. 19]. Отже, між ними повинен існувати постійний динамічний зв'язок, що полягає у взаємному корегуванні та впливі.

Говорячи про суть процесів децентралізації, слід говорити що їх кінцевою метою $є$ формування нової форми територіальної організації державної влади на місцях, 3 чіткими та нормативно визначеним розмежуванням повноважень між державними органами влади та місцевим самоврядуванням, закріплення на законодавчому рівні основи для дієвої місцевої демократії та громадської участі у вирішенні місцевих питань та запровадження інститут політичної місцевої відповідальності. Отже, саме показники ефективності діяльності ОТГ і є основним критерієм для визначення успішності реформи децентралізації в Україні.

Таким чином, аналізуючи дані етапи процесу об'єднання можна зазначити, що він відбувається 3 активним залученням місцевої громади, з врахуванням їх пропозицій та обговорень, що $\epsilon$ обов'язковим для визнання законності процесу та прийняття остаточного рішення.

Місцеве самоврядування виступає як інститут публічної влади, і водночас воно $є$ також формою безпосередньої участі населення у вирішенні місцевих проблем. За забезпечення цього місцеве самоврядування має відповідати певним показникам (рис. 1).

Отже, ознаками розвинутого місцевого самоврядування є:

- прозорість та відкритість діяльності й намірів органів та посадових осіб місцевого самоврядування;

- доступність органів місцевого самоврядування для безпосередніх звернень громадян та ефективність зворотного зв'язку;

- антикорупційна стійкість органів місцевого самоврядування;

- широке використання на місцевому рівні механізмів прямої демократії та громадського консультування.

Отже, публічну владу можливо визначити як трансформовану суспільну владу у процесі історичного розвитку, а державна та місцева влада є видами та формами ії реалізації. 


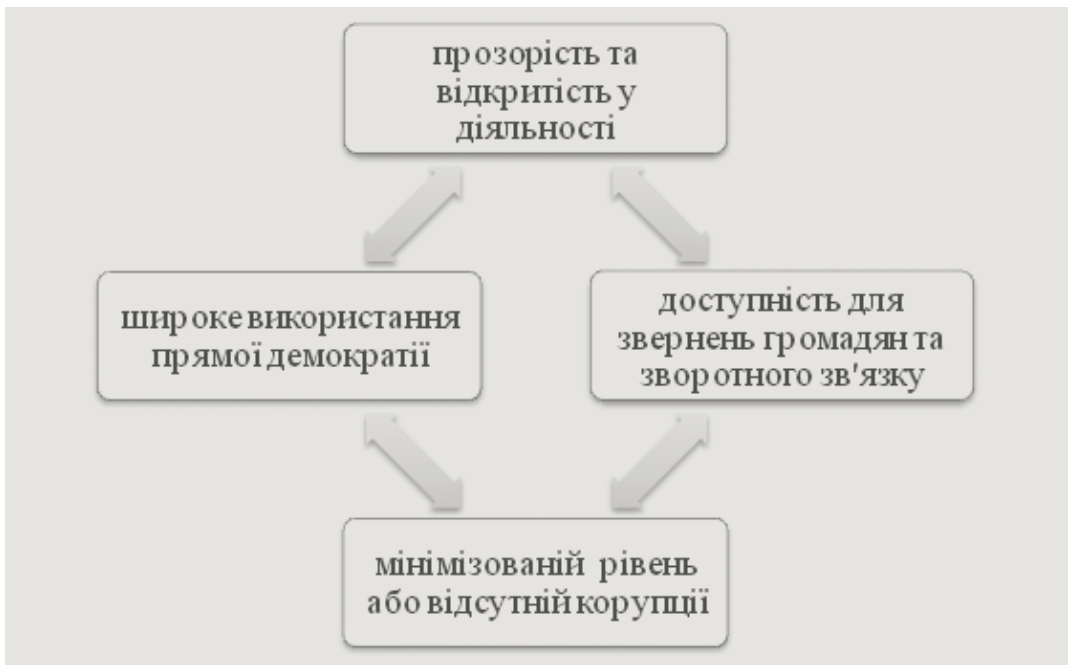

Puc.1. Ознаки розвинутого місцевого самоврядування

Перш за все слід звернути увагу, що прозора та відкрита влада 3 однією з необхідних передумов сталого демократичного розвитку держави та суспільства. Лише за таких умов політика публічної влади буде ефективною, 3 дієвим та реальним громадським контролем, 3 дотриманням принципів захисту прав та свобод людини та зміцнюючи рівень довіри населення до влади.

Прагнення до забезпечення відкритості та прозорості на належному рівні являє собою однією зі складових стратегічного розвитку нашої держави, тому що це так само є загальновизнаним стандартом та принципом функціонування органів публічної влади й загалом політичної культури у розвинених країнах. Проте, на сьогодні рівень відкритості та прозорості влади в України хоч є зростає, проте ще не відповідає стандартам $Є С$, що було неодноразово відмічено міжнародними експертами.

Варто відмітити, що питання прозорості та відкритості влади пов'язують 3 корупцією, адже за умови підвищення даних показників рівень корупції зменшується. Публічна влада, будучи відкритою та прозорою, в тому числі і щодо використання 
бюджетних зменшує ризики можливих різноманітних зловживань, маніпуляцій і порушень, що наявні в діяльності органів державної влади, оскільки відсутність звітування може стати підгрунтям для корупційних проявів.

Принцип відкритості й прозорості в діяльності органів публічної влади закріплені у міжнародно-правових актах. Зокрема, відповідно ч. 2 ст. 6 «Конвенції про доступ до інформації, участь громадськості в процесі прийняття рішень та доступ до правосуддя 3 питань, що стосуються довкілля» [13], ратифікованої Законом України від 6 липня 1999 року № 832-XIV, громадськість повинна адекватно, своєчасно й ефективно одержувати інформацію залежно від обставин шляхом публічного повідомлення або в індивідуальному порядку на початковому етапі процедури прийняття рішень [19, с. 68].

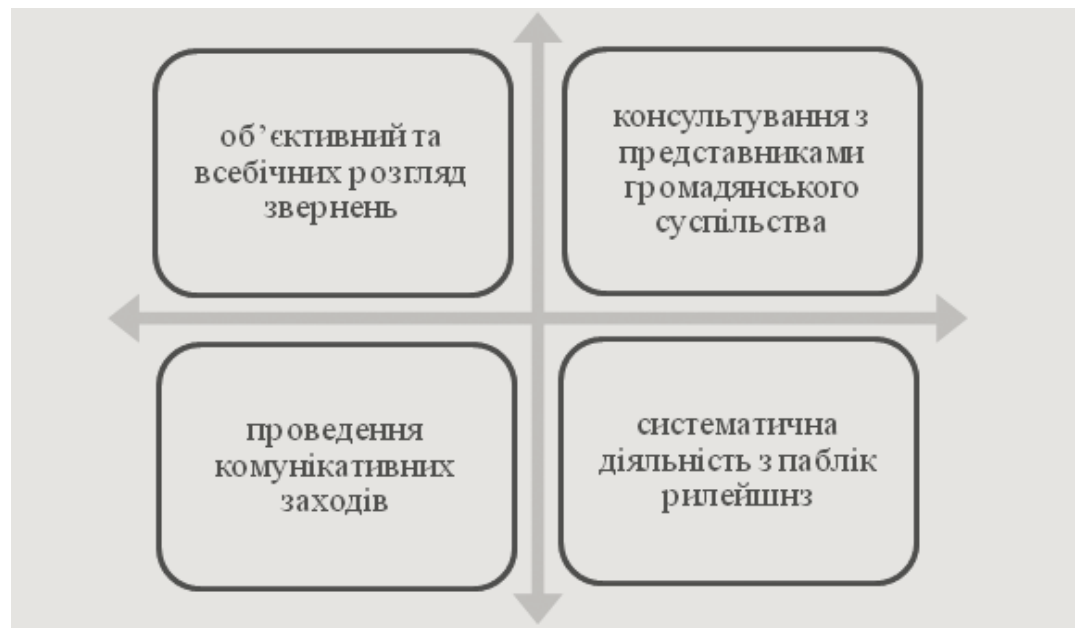

$\boldsymbol{P u c . 2 . ~ О с н о в н і ~ н а п р я м к и ~ р е а л і з а ц і і ̈ ~ п р и н ц и п і в ~ п р о з о р о с т і ~}$ та відкритості діяльності органів публічної влади

До основних напрямків практичної реалізації принципів відкритості і прозорості діяльності органів публічної влади (рис. 2) можемо віднести наступні: 
- об’єктивний та всебічних розгляд звернень громадян, запитів на доступ до публічної інформації до органу публічної влади (а рамках його компетенції);

- консультування 3 представниками громадянського суспільства за важливими питаннями;

- проведення прес конференцій, круглий столів, публічних обговорень, брифінгів в органі публічної влади 3 залученням представників засобах масової інформації;

- систематична робота над комунікацією та висвітленням діяльності органів публічної влади у засобах масової інформації та інші регламентовані і нормативно закріплені дії органів державного управління із висвітлення своєї діяльності та залучення громадськості, громадських об'єднань та організацій до державних справ [17, с. 281].

Перш за все варто приділити увагу питанням теоретичного визначення принципів прозорості та відкритості. Адже дані категорії $\epsilon$ предметом вивчення не лише науки державного управління, а й філософії, політології, економіки, соціології, юриспруденція, що свідчить про міждисциплінарність їх використання та, відповідно, тлумачення. Окрім цього, дані поняття у побутовому розумінні часто ототожнюють між собою, хоча вони є самостійними у застосування та реалізації.

Додержання принципу прозорості передбачає забезпечення доступу громадськості до достовірної, повної та об'єктивної інформації, котра знаходиться у віданні владного органу. 3 іншого боку, принцип відкритості грунтується на спроможності громадян чинити вплив на діяльність влади з прийняття управлінських рішень та разом формувати й впроваджувати публічну політику [26, с. 27].

3 приводу тлумачення категорії «відкритий» слід говорити, що під ним розуміють аналог слів доступний, неприхований, незакритий, необмежений для будь-кого та повсякчасно.

Прозорість можемо визначити як заборону органам публічної влади приховувати від громадськості певну інформацію, яка становить суспільний інтерес, стосується виконання органом його повноважень, або ж як вимогу максимально доступно формулювати цю інформацію. 
А втім, слід відмітити, що рівень прозорості та відкритості може змінюватись 3 часом. Прозорість публічної влади можливо тлумачити у декількох проявах: як засіб підзвітності влади, як регулятивний захід, як засіб покращення ефективності. Щодо характеристики прозорості як засобу підзвітності влади, то даний принцип проявляє себе у звітуванні публічних органів, посадових осіб, долучення до прийняття рішень громадськості.

Так, за результатами дослідження, проведене Трансперенсі Інтернешнл Україна [27], дозволяє говорити про те, що в Україні на сьогодні ще гостро стоїть проблема підзвітності органів публічної влади (рис. 3).

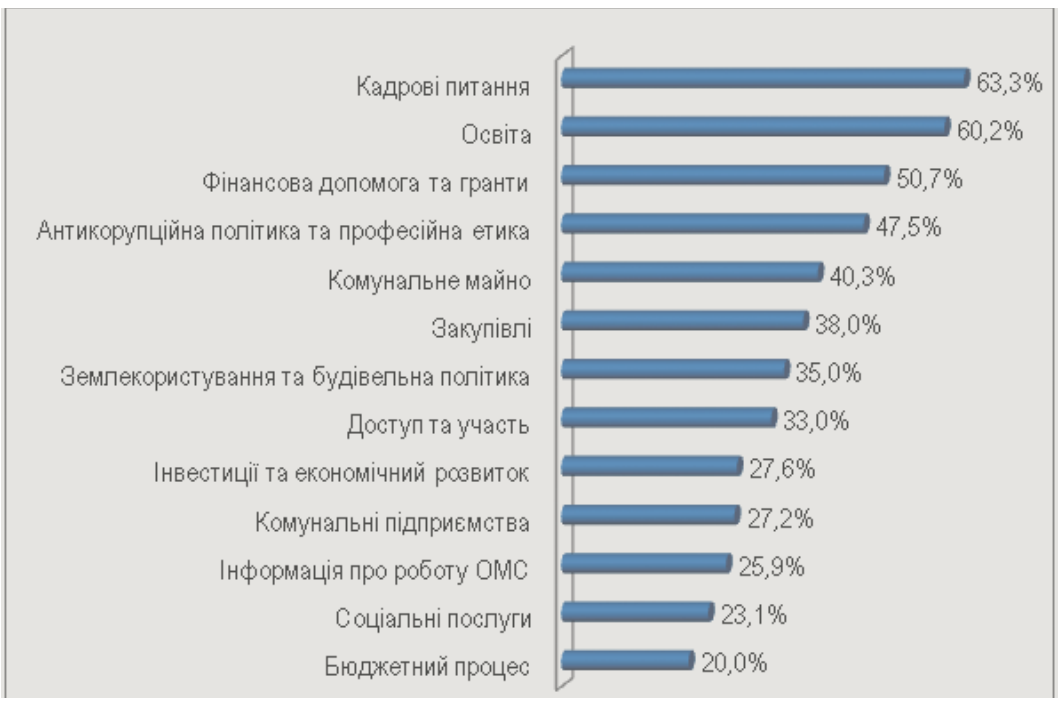

Puc. 3. Виконання індикаторів підзвітності за сферами

Згідно наведеної діаграми переважна більшість сфер діяльності влади за показниками підзвітності не доходить до 50 \%, що в свою чергу негативно впливає на імідж влади, сприйняття іiі суспільством та готовність співпрацювати.

Як регулятивний засіб прозорість $є$ формою контролю. Адже публічна влада керується положеннями законодавства під час 
оприлюднення інформації про свою діяльність [18, с. 321]. Щодо прозорості як підвищення ефективності, то тут має місце більше психологічних аспект та питання щодо відповідальності за не виконання своїх функціональних обов'язків органом в цілому або певною посадовою особою.

Стосовно ж розуміння поняття «відкритість», то у контексті принципу публічної влади іiі варто розуміти як те, що поведінка iii органів повинна бути передбачуваною та врегульованою законодавством, владні функції повинні здійснюватися відповідно до норм законодавства.

Так, прозорість тісно пов'язана 3 принципами верховенства закону, відповідності закріпленим стандартами [9, с. 36].

Отже, публічна влада має своїм завданням забезпечити принципи прозорості та відкритості у діяльності своїх органів. Говорячи на дані принципи як ті, що панують у країнах $\mathrm{CC}$, варто зазначити, що у наукових працях європейських дослідників вони переважно розглядаються у рамках концепції «належного урядування».

Щодо розмежування принципів відкритості та прозорості, то варто зазначити, що вони у відповідності до свого функціонального та змістовного навантаження чітко відрізняються. Це в свою чергу призводить до різного обсягу зобов'язань органів публічної влади перед громадянами.

Таким чином, принципи прозорості та відкритості на практиці фактично не можуть реалізовуватись один без одного, через те що неможливо забезпечити абсолютну відкритість владних органів без достатнього рівня обізнаності громадян [4, с. 46].

Прозорість можна визначити як принцип публічної влади, рівень забезпеченості якого визначається через обізнаність громадян щодо різних аспектів діяльності органів державної влади та місцевого самоврядування, і насамперед - щодо бюджетного аспекту, та обізнаність щодо практичної реалізації рішень органів публічної влади.

Відкритість можна визначити як принцип публічно влади, рівень забезпечення якої визначається безпосереднім залученням громадян у діяльності органів державної влади та місцевого самоврядування. 
Даний принцип виявляється у забезпеченні активного і реального впливу громадянського суспільства зміст публічної діяльності через висування певних вимог перед органами публічної влади щодо прийняття суспільно-важливих рішень, здійснення дій або утримання від них.

У той же час, дані принципи постійно йдуть поруч, тому деякі науковці відстоюють підхід щодо розбудови засадничого поняття - принципу транспарентності, що в тісному взаємозв'язку поєднує категорії прозорості та відкритості, які визначають форми та способи функціонування органів державної влади та місцевого самоврядування у демократичній державі [26, с. 28].

Щодо проблематики забезпечення даних принципів на практиці, то варто зазначити, що найбільшою перешкодою для їх реалізації $\epsilon$ застарілі та не демократичні традиції та засади діяльності органів публічної влади, більшість 3 яких була отримана «у спадок» від радянського режиму.

Так, більше всього спротиву має відкритість влади, адже не завжди у свідомості працівників, посадових осіб та керівників того чи іншого органу публічної влади $є$ розуміння необхідності його дотримання, адже відкритість влади настільки ж залежить i від суспільства, від суспільного запиту про державну інформацію, наскільки вона залежить від самої держави.

Засобами реалізації прозорості є надання вільного доступу до інформації, що відображає діяльність органів публічної влади, та попереднє інформування про рішення, які орган має намір прийняти або ухвалити, надання громадськості можливість висловити свою думку з цього приводу.

Складовою забезпечення прозорості в діяльності органів публічної влади є покладання на них обов'язку інформувати громадськість про організацію своєї діяльності. Сьогодні інформаційні технології дозволяють реалізовувати таку взаємодію. Можливість висвітлення діяльності органів влади в мережі Інтернет (на власних веб-сайтах) - це лише невелика частина від загальної кількості варіантів інформування органами влади про свою діяльність. 
Таким чином, відкритість та прозорість - основні вимоги для ефективного функціонування державної влади, яка сформована демократичним шляхом. У разі недотримання таких вимог громадський контроль за діяльністю влади $€$ неможливим. А закритість та непрозорість в діяльності органів влади, навпаки, сприяє iі корупційності, через що знижується довіра до органів публічної влади в цілому [15, с. 161].

Говорячи про практичну реалізацію даних принципів, не можливо не зазначити про оцінку публічної влади і їі відкритості та прозорості з боку громадянського суспільства. Адже на сьогодні авторитетні громадські організації на міжнародному рівні мають таку ж вагу, як i, наприклад, міжнародні органи, моніторингові місії, i їх оцінка є дуже вагомою [25, с. 151].

Сьогодні перед державою постає питання формування єдиного підходу до заходів i механізмів ефективного партнерства та взаємодії держави та громадянського суспільства, що має підвищити результативність діяльності органів публічної влади і збільшення рівня довіри до органу з боку суспільства.

Забезпечення інформаційної відкритості та прозорості органів публічної влади $є$ гарантією для встановлення громадського контролю за усіма їх діями. В цілому, громадський контроль виступає опорним інструментом забезпечення відкритості та прозорості у діяльності влади (рис. 4). Адже шляхом використання інструментів такого контролю (громадські слухання, опитування, запрошення представників громадськості на засідання тощо) також можливо підвищити рівень довіри до органів публічної влади як державного, так і місцевого рівня [6, с. 14-15].

Відкритість також може розглядатись як певна форма доступу до інформації про діяльність влади, про процедури прийняття та виконання державно-управлінських рішень, а також і можливість впливу на діяльність органів державної влади - можливість використовувати та змінювати те до чого вже є доступ. Одним із аспектів забезпечення відкритості та прозорості налагодження діалогу між владою та громадськістю є різноманітні інформаційні стратегії, які відображають відносини та ступінь налагодженості 
співпраці між органом влади та громадянським суспільством, у тому числі - зі засобами масової інформації [20, с. 69].

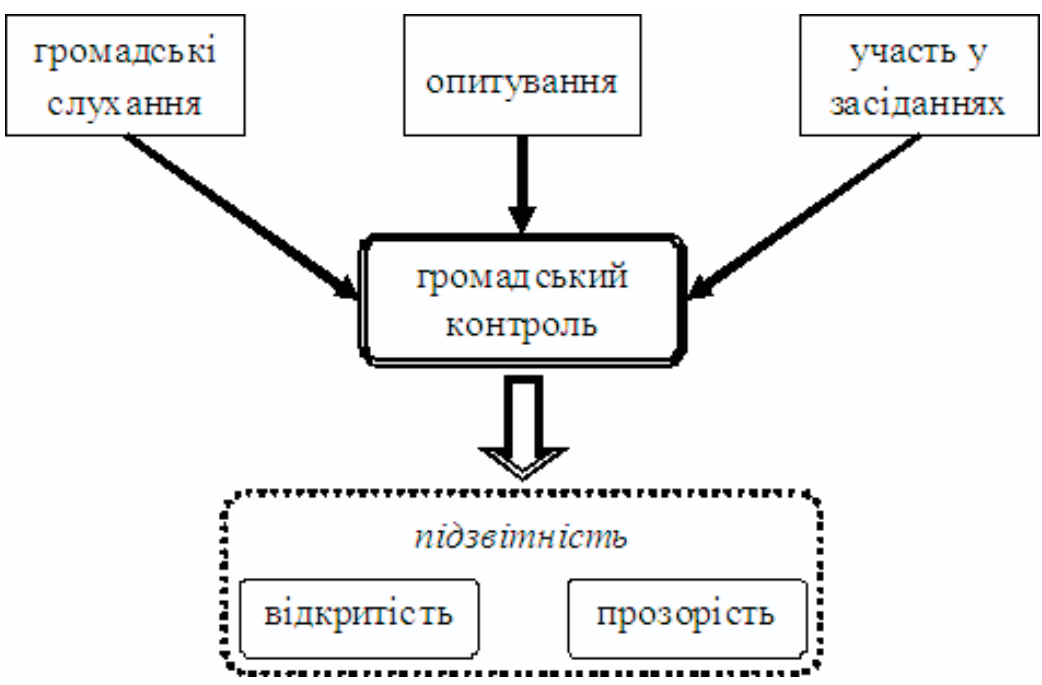

Puc.4. Механізм забезпечення підзвітності органів публічної влади

Однією із форм налагодження взаємодії держави та суспільства $\epsilon$ державна комунікація. В контексті розгляду даного питання на особливу увагу заслуговує розуміння змісту державної комунікації, яка у свої діяльності має виходити із двох площин, а саме: реагувати на запити громадськості, а завдяки цьому здобувати легітимність своїх рішень [2, с. 79].

Отже, принципи прозорості та відкритості органів публічної відіграють одну з найважливіших ролей у демократизації держави й суспільства. Саме прозорість та відкритість органів ілюструє можливість та готовність влади до конститутивного діалогу 3 громадою, громадськими організаціями, ЗМІ та сприяє в цілому у здатність, спроможність і готовність до діалогу для консолідації суспільства в цілому.

Забезпечення прозорості та відкритості в діяльності органів публічної влади, зокрема щодо прийняття ними важливих 
управлінських рішень, інформування населення та зміцнення його довіри до органів влади на державному та місцевому рівні $є$ важливою складовою демократичного суспільства.

Варто зазначити, що рівень довіри громадян до органів державної влади напряму залежить від наявних масштабів корупції в країні. А, у свою чергу, однією з причин корупції є закритість влади від громадськості, відсутність публічних звітувань, через що саме забезпечення прозорості у діяльності органу публічної влади $\epsilon$ важливим елементом підвищення рівня довіри до влади. Однією зі складових прозорості є інформаційна складова, тобто можливість громадян мати доступ до суспільно важливої, публічної інформації про діяльність того чи іншого органу [3, с. 97].

Під час дослідження принципів відкритості та прозорості публічної влади, варто зазначити про три основні аспекти. По-перше, це якість існуючого нормативно-правового поля функціонування влади в контексті відкритості та прозорості. По-друге - це наявність ефективних, законодавчо визначених способів та механізмів реалізації доступу громадян до інформації про владний орган та його діяльність. I по-третє - аспект рівня політичної культури всіх суб'єктів політичного процесу. Можемо зазначити, що на сьогодні в Україні працює законодавство, яка регулює доступ до такої інформації.

Зазначаючи про правове регулювання доступу до публічної інформації варто зазначити, що відповідно до ч.3 ст. 34 Основного Закону, реалізація «права на вільне збирання, зберігання, використання і поширення інформації може бути обмежене виключно законом в інтересах національної безпеки, територіальної цілісності або громадського порядку з метою запобігання заворушенням чи злочинам, для охорони здоров'я населення, для захисту репутації або прав інших людей, для запобігання розголошенню інформації, одержаної конфіденційно, або для підтримання авторитету i неупередженості правосуддя» [14]. Щодо практичного механізму реалізації суб'єктивного конституційного права на доступ до інформації варто зазначити, що закони та нормативні акти 3 даного питання повинні містити наступні норми щодо: 
1) конкретних варіантів можливої поведінки, що у своїй сукупності складають зміст даного права або свободи;

2) умови, за наявності яких у особи виникає можливість реалізовувати конкретні варіанти можливої поведінки, що входять до змісту даного права або свободи;

3) конкретних механізмів та процедур, використовуючи які особа зможе правомірно реалізувати свої права та свободи щодо отримання інформації;

4) негативних наслідків, які настануть для суб'єктів, які ускладнюють або перешкоджають особі в реалізації ії права [5].

Першим нормативним документом незалежної України, який деталізував право громадян на отримання інформації про діяльність органів публічної влади став Закон України «Про інформацію». Так, у законі закріплено права громадян України на інформацію, закладено правові основи інформаційної політики держави та інформаційних відносин [23].

Щодо основного закону, який регулює доступ до публічної інформації, а саме Закону України «Про доступ до публічної інформації», то він був прийнятий 13 січня 2011 р. (набрав чинності 10 травня 2011 р.) [22]. Варто зазначити, що він був прийняти на виконання Резолюції Парламентської Асамблеї Ради Європи 2005 р. «Про виконання обов'язків та зобов'язань Україною» №1466 та 3 метою забезпечення реалізації положень статті 34 Конституції України стосовно свободи інформації, Конвенції про захист прав людини і основоположних свобод 1950 р.. Основною метою прийняття даного закону стало необхідність забезпечення ефективної реалізації права кожного на свободу висловлення власних поглядів та доступ до публічної інформації, «права на вільне збирання, зберігання, використання і поширення інформації усно, письмово або в інший спосіб» [3, с. 97].

Варто зазначити, що під час роботи над законом були залучені представники громадських організацій, а за основу були взяти найкращі практики країн-держав СС у даній сфері.

Публічна інформація, відповідно до положень закону «Про доступ до публічної інформації», «є відображеною та 
задокументованою будь-якими засобами та на будь-яких носіях інформація, що була отримана або створена у процесі виконання суб'єктами владних повноважень своїх обов'язків, передбачених чинним законодавством або яка знаходиться у володінні суб'єктів владних повноважень, інших розпорядників публічної інформації, визначених цим Законом» [22].

Отже, даний нормативно-правовий акт має на меті забезпечити прозорість і відкритість діяльності суб'єктів владних повноважень, які перелічені серед розпорядників інформації. У свою чергу, розпорядниками інформації $є$ ті особи, на яких закон покладає обов'язки із забезпечення доступу до інформації, якою вони володіють.

За загальним правилом, весь обсяг інформації, яка знаходиться у володіння суб'єкта владних повноважень, є публічною. Проте, у той же час, законом визначені чіткі та вичерпні випадки, коли доступ до інформації може бути обмежений, та визначає алгоритм дій отримання практичного доступу особи до інформації [5].

Таким чином, доступ допублічної інформації можназабезпечити, по-перше, через надання відповідей на запити щодо цієї інформації, по-друге, через виконання відповідним органом обов'язку вести облік усіх відомостей та публікувати їх через власний веб-сайт, загально довідкових державних сайтах (інформаційні портали, реєстри тощо) або за допомогою ЗМІ.

Так, як вже було нами зазначено, відповідно до Закону вважає інформацію публічною та поширює відповідний правовий режим на інформацію, яка відповідає таким спеціальним ознакам, вказаним у законі. Тобто публічною є інформація, яка має наступні ознаки:

1. отримана або створена розпорядниками публічної інформації, які визначені законом;

2. була сформована у процесі виконання обов'язків суб'єктів владних повноважень або знаходиться у володінні інших розпорядників, визначених Законом;

3. зафіксована у будь якій формі (на паперових чи електронних носіях), тобто вона може бути зафіксована у вигляді тексту, зображення, плану, таблиці, у розрахункових бухгалтерських 
документах, на аудіо-відео записах, карти, схеми чи фото, запису звуку або відео, тощо.

Закон «Про доступ до публічної інформації» також регулює питання щодо доступу особи до інформації про себе, адже публічна інформація може містить і дані про фізичних та юридичних осіб, та персональні дані. Так, кожна особа також наділена наступними правами відносно інформації про себе:

1. бути усвідомленою про збирання інформації до початку ii використання та про мету збирання такої інформації, ким вона буде використовуватись та ким буде поширена, крім встановлених законом випадків;

2. мати доступ до інформації про себе, яка збирається та зберігається;

3. вимагати корегування неповних, неточних або застарілих відомостей про себе, видалення тієї особистої інформації, збирання чи використання котрої відбувається із порушенням діючих вимог законодавства [8, с. 33].

Основним механізмом доступу до публічної інформації, який активно використовується як фізичними особами, так i зокрема громадськими організаціями для здійснення громадського контролю, є направлення до розпорядника запит на доступ до публічної інформації .

Варто зазначити, що на відміну до Закону України «Про звернення громадян», для подання запиту запитувач може зазначити лише своє ім'я (або найменування), контакту інформацію на яку необхідно направити відповідь (електронна адреса, пошта тощо), описати змісту запитуваної інформації, підписати та датувати запит. Так, особа може не зазначити своє повне ім'я, та не вказувати свій соціальний статус.

Фактично, з точки зору закону, розпоряднику не важлива особа запитувача, він не може запитувати мету використання особою публічної інформації, адже ця інформація є публічною та повинна бути надана на запит не залежно від даних обставин [28, с. 420].

Після реєстрації запиту у розпорядника інформації $є$ п’ять робочих днів для надання відповіді на запит. Такий маленький 
термін встановлений через те, що дана інформація вже створена та зафіксовано, тому для надання відповіді на запит фактично потрібно зробити копію того документу, який містить запитувана інформації. У той же час, у випадку, якщо наданий запит торкається надання значного обсягу інформації чи вимагає пошуку цієї інформації серед великого масиву відомостей, термін розгляду запиту може бути збільшено до 20 робочих днів. За останнього варіанту має надаватись обгрунтування такого продовження терміну. Обов'язковою умовою $€$ надання запитувачу проміжної відповіді протягом 5 робочих днів щодо продовження розгляді запиту.

Окрім цього, у Законі встановлено термін надання запитуваної інформації протягом 48 годин у випадку, якщо інформація $\epsilon$ суспільно важливою та пов'язана 3 ймовірними загрозами життю та здоров'ю громадян, національній безпеці тощо [22] (наприклад, щодо кількість апаратів штучної вентиляції легенів у лікарнях певної адміністративно-територіальної одиниці, які $є$ життєво необхідними для лікування гострої респіраторної хвороби COVID-19, спричиненої коронавірусом SARS-CoV-2).

У разі непогодження 3 наданою розпорядником відповіді, неправомірною відмовою на думку запитувача у наданні інформації, надання інформації 3 порушенням термінів, рішення, дії чи бездіяльність владного органу, у віданні якого ця інформація, можуть бути оскаржені у керівництва, органі вищого рівня чи у суді. Окрім цього, за порушення норм Закону передбачена адміністративна відповідальність за ст. 212-3 Кодексу України про адміністративні правопорушення [12]. Для цього запитувачу необхідно звернутись до Уповноваженого Верховної Ради $з$ прав людини, працівники Секретаріату якого мають повноваження складати протокол про адміністративне правопорушення та направляти на розгляд до суду. Окрім цього, на даний орган покладено функцію контролю за дотримання закону в цілому.

Отже, закон «Про доступ до публічної інформації» має на меті забезпечити прозорість і відкритість діяльності органів публічної влади та регламентує як обов'язок органу самостійно оприлюднювати публічну інформацію, так і надавати іï у відповідь на запит. 
Проте, хоча закон діє вже 10 років, і досі виникають проблеми 3 правовим застосуванням його положень.

Так, органи публічної влади неправомірно застосовують грифи обмеження доступу до інформації (наприклад, відносять до інформації для службового користування листування з іншими органами та установами, у той час як запитувач може запросити той чи інший документ), неналежним чином виконують вимоги щодо оприлюднення інформації про свою діяльність, а наявні засоби інформації не $є$ ефективними (наприклад, опубліковують рішення лише у районні газеті та інформаційних стендах, проте не на сайті). Окрім цього типовою проблемою є відсутність в органах спеціальної посадової особи, яка б була відповідальна за дотримання вимог закону та готувала відповіді на запити на публічну інформації. Особливо актуальна ця проблема є на сьогодні, особливо в ОТГ, у яких бракує кадрів, особливо з юридичною освітою [4, с. 49].

32011 р. діє закон «Про доступ до публічної інформації», котрий встановлює порядок забезпечення та здійснення права громадянина на доступ до публічної інформації, котра знаходиться у віданні органів публічної влади або інших розпорядників інформації, котра становить суспільний інтерес. Зазначений закон за основну мету має «забезпечення прозорості та відкритості суб’єктів владних повноважень і створення механізмів реалізації права кожного на доступ до публічної інформації» [21, с. 245]. Сам доступ до публічної інформації так само відбувається на принципах прозорості та відкритості діяльності суб' єктів владних повноважень.

Прозорість органів влади в контексті доступу реалізується через:

- обов'язки розпорядників публічної інформації надавати та оприлюднювати iii, за виключенням, що передбачено законом;

- організацію доступу до публічної інформації визначеним розпорядником відповідальним підрозділом чи посадовою особою;

- максимальне спрощення процедури подання запиту та отримання інформації;

- можливість приступності на засіданнях колегіальних органів влади, за виключенням випадків, зазначених у законодавстві; 
- здійснення державного та громадського (у т.ч. шляхом проведення громадських експертиз) контролю за дотриманням законних прав на доступ до публічної інформації.

Отже, на сьогодні є проблеми 3 практичним застосування права на доступ до публічної інформації, не зважаючи на те, що це питання має достатнє правове забезпечення. Так, існують негативні приклади нехтувань або порушень ч.2 ст. 34 Конституції України щодо вільного доступу до інформації, не завжди громадяни мають можливість реалізувати його безперешкодно тощо. Іншою проблемою залишаються колізії у законодавстві у даній сфері, що зумовило неоднакове застосування норм права у сфері інформаційних правовідносин, іноді таке застосування має вибірковий чи непостійний характер. У даному контексті невідкладним є одночасне внесення змін, насамперед, до законів «Про інформацію» (який на сьогодні дії, проте вже є моральна застарілим), «Про доступ до публічної інформації» та «Про захист персональних даних», створення прозорих інструментів їх реалізації у повсякденному житті. Вочевидь, на сьогодні досить необхідним та важливим $є$ забезпечення громадського контролю за дотриманням права на доступ до публічної інформації органами публічної влади на місцевому рівні. Особливо актуальним це є для місцевих громадських організацій та членів територіальних громад.

Висновки. Підсумовуючи слід відмітити, що до переваг децентралізованої моделі публічного управління можна віднести реальну форму здійснення місцевого народовладдя у відповідності демократичним принципам управління, врахування в першу чергу саме інтересів і потреб місцевої громади, ефективне та швидке рішення місцевих проблем, розпорядження власними ресурсами, фінансова самостійність. Аналізуючи сьогоднішній етап процесу розбудови системи управління на місцевому рівні можна зазначити, що він відбувається 3 активним залученням місцевої громади, 3 врахуванням їх пропозицій та обговорень, що є обов'язковим для визнання законності процесу та прийняття остаточного рішення. Визначено, що основними ознаками розвинутого місцевого самоврядування є забезпечення прозорості та відкритості; широке 
використання прямої демократії; доступність для звернень громадян та зворотного зв>язку; мінімізованій рівень або відсутній корупції.

Визначено, основні напрямки реалізації принципів прозорості та відкритості діяльності органів публічної влади: об'єктивний та всебічних розгляд звернень; консультування 3 представниками громадянського суспільства; проведення комунікативних заходів; систематична діяльність 3 паблік рілейшнз. Слід відмітити, що рівень прозорості та відкритості може змінюватись з часом. Прозорість публічної влади можливо тлумачити у декількох проявах: як засіб підзвітності влади, як регулятивний захід, як засіб покращення ефективності. Щодо характеристики прозорості як засобу підзвітності влади, то даний принцип проявляє себе у звітуванні публічних органів, посадових осіб, долучення до прийняття рішень громадськості. Зазначається, що публічна влада має своїм завданням забезпечити принципи прозорості та відкритості у діяльності своїх органів. Говорячи на дані принципи як ті, що панують у країнах $\mathrm{CC}$, варто зазначити, що у наукових працях європейських дослідників вони переважно розглядаються у рамках концепції «належного урядування». Сьогодні перед державою постає питання формування єдиного підходу до заходів і механізмів ефективного партнерства та взаємодії держави та громадянського суспільства, що має підвищити результативність діяльності органів публічної влади і збільшення рівня довіри до органу з боку суспільства.

Стаття надійшла до редакції: 09. 01.21

\section{GENERAL PRINCIPLES FOR ENSURING THE OPENNESS AND TRANSPARENCY OF PUBLIC AUTHORITIES IN UKRAINE}

Serhij Tymofieiev, $\mathrm{PhD}$ in Public Administration, Associate Professor of the Department of Public Administration of Petro Mohyla Black Sea National University, Mykolaiv, Ukraine. 
The article is devoted to the study of the general principles of ensuring openness and transparency of public authorities and establishing the peculiarities of the implementation of these principles in Ukraine at the present stage. It is noted that the advantages of the decentralized model of public administration include a real form of local democracy in accordance with democratic principles of governance, taking into account the interests and needs of the local community, effective and rapid solution of local problems, disposal of own resources, financial independence. Analyzing the current stage of the process of building a management system at the local level, it can be noted that it takes place with the active involvement of the local community, taking into account their suggestions and discussions, which is mandatory for recognizing the legality of the process and making a final decision. It is determined that the main features of developed local self-government are ensuring transparency and openness; widespread use of direct democracy; accessibility for citizens' appeals and feedback; minimized level or no corruption.

The main directions of realization of the principles of transparency and openness of activity of public authorities are determined: objective and comprehensive consideration of appeals; consulting with civil society representatives; conducting communication activities; systematic activities in public relations. It is noted that the level of transparency and openness may change over time. Transparency of public authority can be interpreted in several ways: as a means of accountability of power, as a regulatory measure, as a means of improving efficiency. Regarding the characterization of transparency as a means of accountability of the government, this principle manifests itself in the reporting of public bodies, officials, involvement in public decision-making. It is noted that the public authorities have the task to ensure the principles of transparency and openness in the activities of their bodies.

Key words: public authorities, openness, transparency, publicity, accountability, communications.

\section{Received: 09.01.21}




\section{References}

1. Batanov, O.V. (2015). Deiaki kontseptual'ni problemy reformy konstytutsijnoi modeli mistsevoho samovriaduvannia $\mathrm{v}$ suchasnij Ukraini [Some conceptual problems of the reform of the constitutional model of local self-government in modern Ukraine]. Publichne pravo - Public law, 2, (pp. 1825) [in Ukrainian].

2. Bukhanevych, A.I. (2010). Zabezpechennia pryntsypiv vidkrytosti ta prozorosti pry nalahodzhennia dialohu mizh vladoiu ta hromads'kistiu [Ensuring the principles of openness and transparency in establishing a dialogue between the government and the public]. Derzhavne upravlinnia: vdoskonalennia ta rozvytok - Public administration: improvement and development, 3, (pp. 77-82) [in Ukrainian].

3. Vlaschenko, S.S. (2017). Perspektyvy udoskonalennia realizatsii mistsevymy orhanamy vlady prava osoby na dostup do publichnoi informatsii [Prospects for improving the implementation of local authorities' right to access public information]. Nash zakon - Our law, 1, (pp. 92-98) [in Ukrainian].

4. Voronov, M.M. (2015). Pryntsypy hlasnosti, vidkrytosti ta prozorosti na munitsypal'nomu rivni: teoretychnyj aspekt ta vtilennia $\mathrm{v}$ zakonodavstvi Ukrainy [Principles of publicity, openness and transparency at the municipal level: theoretical aspect and implementation in the legislation of Ukraine]. Visnyk Kharkivskoho natsionalnoho universytetu imeni V. N. Karazina. Seriia: Pravo - Bulletin of VN Karazin Kharkiv National University. Series: Law, 19, (pp. 46-50) [in Ukrainian].

5. Hravtsov, M.O. (2018). Dostup do publichnoi informatsii iak relevantnyj faktor zabezpechennia konstytutsijnykh prav hromadian na informatsiiu v Ukraini [Access to public information as a relevant factor in ensuring the constitutional rights of citizens to information in Ukraine]. Visnyk Natsionalnoi akademii Derzhavnoi prykordonnoi sluzhby Ukrainy. Seriia: Derzhavne upravlinnia Bulletin of the National Academy of the State Border Guard Service of Ukraine. Series: Public Administration, 4, (pp.75-75) [in Ukrainian].

6. Hrybko, O.V. (2017). Hromads'kyj kontrol' iak bazovyj instrument zabezpechennia prozorosti ta vidkrytosti systemy publichnoho upravlinnia [Public control as a basic tool for ensuring transparency and openness of the public administration system]. Derzhavne budivnytstvo - State building, 2, (pp. 13-15) [in Ukrainian].

7. Detsentralizatsiia vlady: poriadok dennyj na seredn'ostrokovu perspek tyvu [Decentralization of power: an agenda for the medium term]. Kyiv: NIDS [in Ukrainian]. 
8. Dmytrenko, E.S. (2019). Osoblyvosti opryliudnennia sub'iektamy hospodariuvannia informatsii pro vykorystannia publichnykh koshtiv [Peculiarities of publishing information on the use of public funds by business entities]. Ekonomika ta pravo-Economics and law, 1, (pp. 32-37) [in Ukrainian].

9. Dronov, V.Yu. (2017). Prozorist' ta vidkrytist' iak vykhidni zasady realizatsii osvitn'oi funktsii suchasnoi derzhavy: teoriia ta zakonodavche rehuliuvannia [Transparency and openness as the basic principles of realization of the educational function of the modern state: theory and legislative regulation]. Visnyk Chernivetskoho fakultetu Natsionalnoho universytetu "Odeska yurydychna akademiia» - Bulletin of the Chernivtsi Faculty of the National University "Odessa Law Academy», 2, (pp. 32-44) [in Ukrainian].

10. Yevtushenko, O.N. (2010). Derzhavna vlada i mistseve samovriaduvannia v Ukraini: mozhlyvi modeli vzaiemovidnosyn [State power and local self-government in Ukraine: possible models of relations]. Naukovi pratsi. Seriia: Politolohiia - Scientific works. Series: Political Science, 149 (137), (pp. 83-87).

11. Kovtun, Yu. (2019). Uporiadkuvannia polia funktsij systemy orhaniv publichnoi vlady v umovakh detsentralizatsii [Streamlining the field of functions of the system of public authorities in the context of decentralization]. Aktualni problemy derzhavnoho upravlinnia - Actual problems of public administration, 1, (pp. 54-59) [in Ukrainian].

12. Kodeks Ukrainy pro administratyvni pravoporushennia: No $8073-\mathrm{X}$ vid 07.12.1984 r. [Code of Ukraine on Administrative Offenses: No 8073-X from 07.12.1984]. zakon.rada.gov.ua. Retrieved from https://zakon.rada.gov.ua [in Ukrainian].

13. Konventsiia pro dostup do informatsii, uchast' hromads'kosti v protsesi pryjniattia rishen' ta dostup do pravosuddia z pytan', scho stosuiut'sia dovkillia [Convention on Access to Information, Public Participation in Decision-Making and Access to Justice in Environmental Matters]. zakon.rada.gov.ua. Retrieved from https://zakon.rada.gov.ua [in Ukrainian].

14. Konstytutsiia Ukrainy vid 28 chervnia $1996 \mathrm{r}$. [Constitution of Ukraine from June 28, 1996]. zakon.rada.gov.ua. Retrieved from https://zakon.rada.gov. ua [in Ukrainian].

15. Kuspliak, I. (2015). Prozorist' ta vidkrytist' vlady: vid kontseptu "prozoroho mista" do portalu vidkrytykh danykh [Transparency and openness of government: from the concept of a "transparent city" to an open data portal]. Teoretychni ta prykladni pytannia derzhavotvorennia - Theoretical and applied issues of state formation, 16, (pp. 159-171) [in Ukrainian]. 
16. Lopushyns'kyj, I.P. \& Olenkovs'ka, L.P. (2015). Reformuvannia mistsevoho samovriaduvannia iak osnova vprovadzhennia detsentralizatsijnykh modelej upravlinnia [Reforming local self-government as a basis for implementing decentralization management models]. Teoriia $i$ praktyka derzhavnoho upravlinnia ta mistsevoho samovriaduvannia - Theory and practice of public administration and local self-government, 1. Retrieved from http://el-zbirn-du.at.ua [in Ukrainian].

17. Mytsak, B. \& Ivakha, V. (2010). Realizatsiia pryntsypiv vidkrytosti i prozorosti orhaniv derzhavnoho upravlinnia $\mathrm{v}$ Ukraini [Implementation of the principles of openness and transparency of public administration in Ukraine]. Naukovi zapysky Lvivskoho universytetu biznesu ta prava - Scientific notes of Lviv University of Business and Law, 5, (pp. 280-283) [in Ukrainian].

18. Minaieva, I.M. (2018). Vidkrytist' i prozorist' diial'nosti orhaniv publichnoi vlady [Openness and transparency of public authorities]. Teoriia i praktyka derzhavnoho upravlinnia - Theory and practice of public administration, 4, (pp. 320-326) [in Ukrainian].

19. Nesterovych, V.F. (2016) Pryntsypy vidkrytosti ta prozorosti v diial'nosti orhaniv derzhavnoi vlady iak peredumova utverdzhennia demokratii uchasti [Principles of openness and transparency in the activities of public authorities as a prerequisite for the establishment of participatory democracy]. Filosofsko-metodolohichni problemy prava-Philosophical and methodological problems of law, 2, (pp. 67-77) [in Ukrainian].

20. Nironka, Yu. (2019). Sutnist' hromads'koho kontroliu za diial'nistiu orhaniv publichnoi vlady [The essence of public control over the activities of public authorities]. Zakon pro potochni spravy - Current Affairs Law, 2, (pp. 67-77) [in Ukrainian].

21. Parubchak, I. O. (2017). Rol' zasobiv masovoi informatsii u vzaiemodii orhaniv publichnoi vlady iz suspil'stvom na zasadakh vidkrytosti ta prozorosti [The role of the media in the interaction of public authorities with society on the basis of openness and transparency]. Visnyk Natsionalnoho universytetu tsyvilnoho zakhystu Ukrainy - Bulletin of the National University of Civil Defense of Ukraine, 2, (pp. 239-249) [in Ukrainian].

22. Pro dostup do publichnoi informatsii: Zakon Ukrainy No $2939-\mathrm{V}$ vid 13.01.2011r. [On access to public information: Law of Ukraine No 2939-V from 13.01.2011]. zakon.rada.gov.ua. Retrieved from https://zakon.rada.gov.ua [in Ukrainian].

23. Pro informatsiiu: Zakon Ukrainy No $2657-X$ vid 02.10 .1992 r. [About information: Law of Ukraine No 2657-X from 02.10.1992]. zakon.rada.gov.ua. Retrieved from https://zakon.rada.gov.ua [in Ukrainian]. 
24. Semenchenko, F.H. (2010) Orhany mistsevoho samovriaduvannia v systemi publichnoi vlady [Local governments in the system of public authority]. Naukovi pratsi. Seriia: Politolohiia-Scientific works. Series: Political Science, 149 (137), (pp. 95-99) [in Ukrainian].

25. Tymofieiev, S.P. (2019). Rol' prozorosti i vidkrytosti orhaniv vlady u rozbudovi hromadians'koho suspil'stva [The role of transparency and openness of government in building civil society]. Derzhavne upravlinnia ta rehionalnyi rozvytok - Public administration and regional development, 3, (pp. 142-161) [in Ukrainian].

26. Tkach, I.V. (2016). Pryntsypy prozorosti ta vidkrytosti iak nevid'iemna skladova publichnoho upravlinnia: teoretychnyj aspekt [Principles of transparency and openness as an integral part of public administration: a theoretical aspect]. Mizhnarodnyi naukovyi zhurnal «Internauka»-International scientific journal «Internauka», 12 (1), (pp. 25-32) [in Ukrainian].

27. Transparency International Ukraine. ti-ukraine.org. Retrieved from https://ti-ukraine.org [in Ukrainian].

28. Shoturma, N.V. (2015). Zabezpechennia dostupu do publichnoi informatsii $\mathrm{v}$ mistsevykh orhanakh vykonavchoi vlady [Ensuring access to public information in local executive bodies]. Hileia - Gilea, 94, (pp. 418-422) [in Ukrainian].

\section{Відомості про авторів / Information about the Authors}

Тимофсєв Сергій Павлович: Чорноморський національний університет ім. Петра Могили: вул. 68 десантників 10, Миколаїв, 54003, Україна.

Serhij Tymofieiev: Petro Mohyla Black Sea National University: 68 Desantnykiv str. 10, Mykolaiv, 54003, Ukraine.

\section{ORCID.ORG/ 0000-0002-9223-1468}

\section{E-mail: stymofeev@gmail.com}

